\title{
Allelopathy of weeds on the growth of vegetables
}

\author{
Ines Rezendes ${ }^{1}$, Ediane Roncaglio Baseggio ${ }^{1}$, Leandro Galon ${ }^{1 *}$, Daiani Brandler ${ }^{1}$, César Tiago Forte ${ }^{1}$, \\ Ignacio Aspiazú ${ }^{2}$, Milena Barretta Franceschetti ${ }^{1}$ and Alexandre Ferreira da Silva ${ }^{3}$
}

${ }^{1}$ Federal University of Fronteira Sul, Erechim, RS, Brazil.
${ }^{2}$ State University of Montes Claros, Janaúba, MG, Brazil.
${ }^{3}$ Embrapa Milho e Sorgo, Sete Lagoas, MG, Brazil.
${ }^{*}$ Author for correspondence: leandro.galon@uffs.edu.br

OPEN ACCESS

(c) The Authors

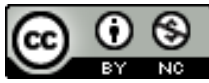

Submitted on November 01, 2019 Accepted on April 09, 2020 Early View on April 17, 2020 Final Publication on April 20, 2020

Authors declare no conflict of interest

KEYWORDS: Cyperus difformis Commelina benghalensis Galinsoga parviflora Aqueous extracts Allelopathy

\section{ABSTRACT}

The use of allelopathy emerges as an alternative method for weed management in crops, especially in small vegetable producing properties. Thus, the objective of this work was to identify possible allelopathic effects of aqueous extracts of the weeds Cyperus difformis $\mathrm{L}$. (small-flowered nutsedge), Commelina benghalensis L. (benghal dayflower) and Galinsoga parviflora Cav. (gallant soldier) on seed germination and seedling growth of Lactuca sativa $\mathrm{L}$. (lettuce) and Lycopersicum esculentum L. (tomato). Two experiments were carried out in a completely randomized design with five replications, the first with lettuce seeds and the second with tomato seeds submitted to germination in five concentrations of weeds aqueous extracts $(0,25,50,75$ and $100 \%)$. All treatments with aqueous extracts of the three species, at different concentrations, caused a reduction in lettuce and tomato root length. There was a reduction in most of the evaluated variables, and seed germination of the crops had the lowest influence of the extracts. The weeds benghal dayflower, small-flowered nutsedge and gallant soldier showed allelopathic potential on lettuce and tomato crops. This potential allelopathic effect is directly related to the concentration and type of extract from the plant species. In general, it can be noted that the greatest allelopathic effect occurred with the use of small-flowered nutsedge extract, followed by gallant soldier and benghal dayflower.

\section{Highlighted Conclusions}

1. Weeds $C$. benghalensis, $C$. difformis and $G$. parviflora show allelopathic potential on the growth of $L$. sativa and $L$. esculentum.

2. Highest allelopathic effect is caused by the extract of $C$. difformis, followed by $G$. parviflora and $C$. benghalensis.

3. The potential allelopathic effect of weeds is directly related to the plant species used, as well as to the concentration of the aqueous extract present in the environment.

\section{INTRODUCTION}

Currently, weed control is mostly carried out using herbicides, often being applied in an indiscriminate and inappropriate manner, increasing the selection pressure and, consequently, the number of cases of resistant species (Heap 2019). This results in an increase in weed management costs or even in higher competitiveness of these species with the crop, thus reducing productivity and quality of harvested products (Silva et al. 2007).

In addition to the concern with weed management, due to the high number of cases of resistance to herbicides, there is also pressure from society to produce healthier foods (Kong 2010). The need for new management methods such as cultural, physical, biological, preventive, mechanical and integrated, aiming at higher efficiency in the control of weeds becomes essential (Rizzardi 2011). In this way, allelopathy and its possible applications can improve weed control, through synergism with other control methods, including the use of herbicides (Hussain et al. 2011, Jabran et al. 2015).

The term allelopathy can be defined as the harmful or beneficial effect, direct or indirect, that a plant causes on its neighbor due to the production of chemicals released into the environment, by processes such as leaching, volatilization, root exudation or decomposition (Inderjit and Callaway 2003). However, the composition and quantity of these compounds depend on environmental conditions, plant species involved in the process, its evolution and its defense strategies (Silva 2012). 
Allelopathic substances, such as phenolic derivatives, alkaloids, coumarins, terpenoids, flavonoids, ethylenes and other secondary metabolites can inhibit or stimulate the growth and development of plants and microorganisms in the surroundings (Fujji et al. 2004, Rashid et al. 2010). These substances can act in several processes of the affected plants, such as germination, physiological processes, synthesis and enzymatic activities (Vasconcelos et al. 2012). Thus, allelopathy can be an important tool in the management of certain weed species in crops. (Rezende et al. 2003, Kong 2010).

Cyperus difformis L., a weed belonging to the Cyperaceae family, is an annual plant, erect and herbaceous, devoid of rhizomes and tubers, with trigonous stem. Commelina benghalensis L. belongs to the Commelinaceae family, and is a perennial plant that reproduces by seeds and vegetative part. Galinsoga parviflora Cav. belongs to the Asteraceae family and is popularly called gallant soldier, an annual short-cycle plant (Lorenzi 2017). These weeds stand out as the most problematic in winter and summer crops in southern Brazil, so it is necessary to study the use the phytotoxic substances of these plants in the development of species of agronomic interest, such as lettuce (Lactuca sativa) and tomatoes (Lycopersicum esculentum).

Lettuce and tomatoes are considered fast-germinating plants, sensitive to secondary metabolites, so they can be used as bioindicators of weed allelopathic activity (Ferreira and Aquila 2000, Cândido et al. 2010).

Thus, the aim of this study was to identify possible allelopathic effects of aqueous extracts from the weeds Cyperus difformis L. (small-flowered nutsedge), Commelina benghalensis L. (Benghal dayflower) and Galinsoga parviflora Cav. (gallant soldier) on seed germination and seedling growth of Lactuca sativa L. (lettuce) and Lycopersicum esculentum L. (tomato).

\section{MATERIAL AND METHODS}

Collection of plants and conduction of the experiments. The experiments were installed and conducted at the Biotechnology Laboratory of the Federal University of Fronteira Sul (UFFS), Campus Erechim / RS. For the production of the extracts, shoots of Cyperus difformis, Commelina benghalensis and Galinsoga parviflora were used, collected in the municipality of Erechim/RS, in October 2014, during the early hours of the day and stored in duly identified plastic bags. Then, they were taken to the laboratory, where asepsis was performed with $5 \%$ sodium hypochlorite $(1 \mathrm{~min})$ followed by three washes with distilled water. Afterwards, it was left for $30 \mathrm{~min}$ on paper towels so that the water could drain from the material. The production of the crude aqueous extract (CAE) was carried out by grinding in an industrial blender with distilled water, in the proportion of 1:1 $(1 \mathrm{~kg}$ of fresh matter:1 L of distilled water).

After grinding, the material was filtered through sieves and gauze until no residue was left. The extract of each plant was stored in a properly closed plastic container, wrapped in brown paper so that it would not oxidize, identified and stored in a freezer until the time of use. From the crude extracts, dilutions were made using distilled water to obtain the desired concentrations.

Disinfection of lettuce and tomato seeds was carried out with $2 \%$ sodium hypochlorite for 10 seconds, and three consecutive washes with distilled water. Twenty lettuce and tomato seeds from Isla® seeds were sown in Gerbox boxes, in which three sheets of Germitest paper were used, moistened with $15 \mathrm{~mL}$ of aqueous extracts from the three proposed weeds.

Design of the experiments. The experiments were conducted in a completely randomized design with five replications. Two experiments were carried out with 15 treatments, in a $3 \times 5$ bifactorial form, one for the lettuce and the other for tomatoes. In factor $A$ were the species with allelopathic potential $(C$. benghalensis, $C$. difformis and G. parviflora) and in factor B the concentrations of the extracts $(0,25,50,75$ and $100 \%$, with $0 \%$ being the control without extract).

Evaluated variables. The experiments were conducted in a BOD germination chamber at temperatures of $25^{\circ} \mathrm{C}$ for $L$. sativa seeds and $18{ }^{\circ} \mathrm{C}$ for lettuce seeds, and photoperiod for both $12 / 12 \mathrm{~h}$ (light/dark) for 7 days and 14 days (L. esculentum), according to the Seed Analysis Rules - SAR (Brasil 2009).

Regarding the effect of the aqueous extracts of $C$. difformis, $C$. benghalensis and $G$. parviflora on the germination of $L$. sativa and $L$. esculentum seeds, the following analyzes were carried out: Germination percentage (\%): we counted seedlings or roots emerged on the 7th day for L. sativa and on the 14th day for L. esculentum, after sowing, according to RAS (Brasil 2009). Germination speed index: conducted together with the germination test, we counted daily the germinated seeds. The germination speed index was evaluated every $24 \mathrm{~h}$, being determined by adding the ratio between the number of seeds germinated in the day and the number of days (Fernandes et al. 2007). Average length of seedlings and roots: after the emergency test, the length of the seedlings and roots was measured with a digital caliper and the result expressed in millimeters per seedling. Fresh and dry matter: firstly, the fresh matter was determined together, with shoots and radicle. Afterward, the dry matter 
was determined by placing the material in kraft paper bag, previously identified, which was placed in a forced air circulation oven at a temperature of $65^{\circ} \mathrm{C}$ for $48 \mathrm{~h}$. After cooling, the dry matter was determined and expressed in mg.

Statistical analysis. The averages were subjected to analysis of variance by the $\mathrm{F}$ test and, when significant, were compared using the Tukey test for the qualitative factor and regressions for the quantitative factor. All tests were performed at $p<0.05$.

\section{RESULTS AND DISCUSSION}

Preliminary tests. In relation to the vigor characteristics of the seeds examined with the cold test and the accelerated aging test, the results showed a percentage of normal seedlings for $L$. sativa of $100 \%$ for the cold test and $98 \%$ for the accelerated aging test; for L. esculentum, the value for the cold test was $99.2 \%$ and for accelerated aging $97.2 \%$ (data not shown). Thus, the tests proved that the seeds showed adequate vigor to later carry out the germination test under the effect of aqueous extracts from the three species of weeds, since these tests are widely used to determine the vigor and quality of seeds (Barros et al. 1999).

In this way, the results of experiment I will be presented, involving the effect of extracts from weeds $C$. benghalensis, $C$. difformis and G. parviflora on $L$. sativa and later for experiment II on $L$. esculentum.

Experiment I - Influence of weed extracts on the growth of $L$. sativa. The results demonstrate that the increase in the concentrations of aqueous extracts of $C$. benghalensis, $C$. difformis and $G$. parviflora negatively influenced the root length of $L$. sativa seedlings. When comparing the control in relation to $100 \%$ concentration, these extracts reduced root development by $84.0 \%$, while for the other extracts they decreased by 68.3 and $73.6 \%$, respectively (Figure 1A).

A

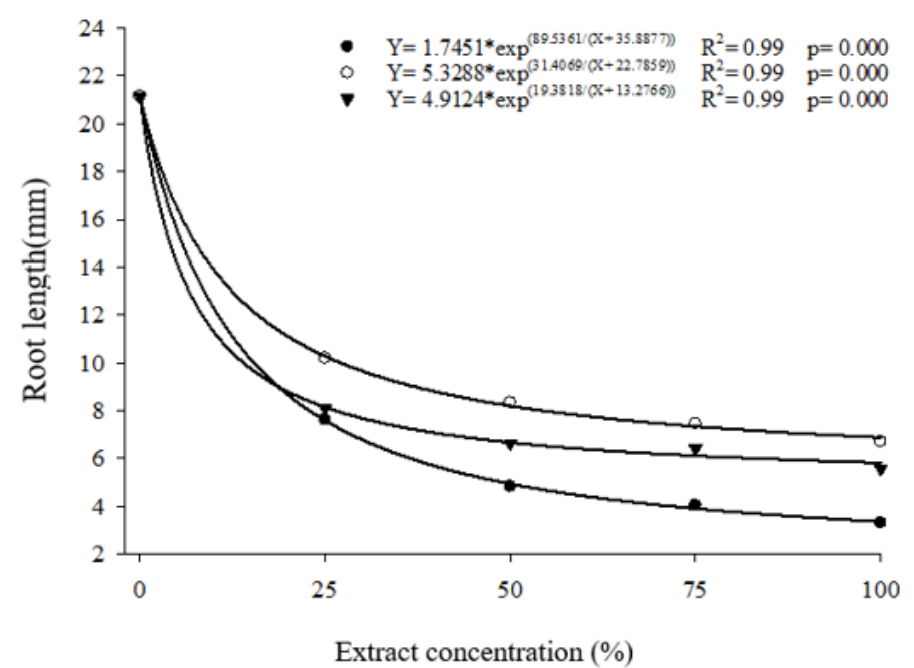

B

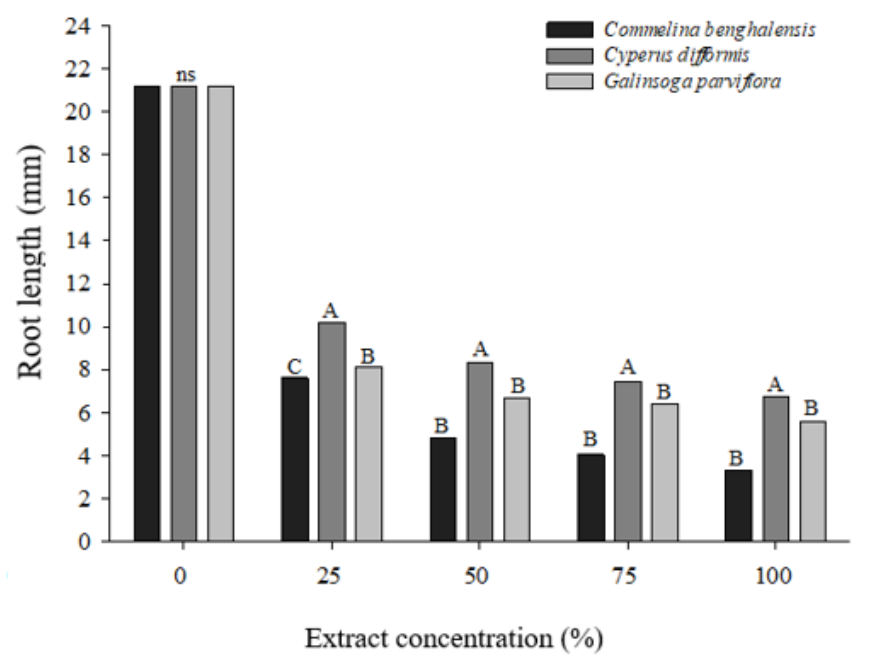

Figure 1. Root length $(\mathrm{mm})$ of Lactuca sativa seedlings as a function of the concentration of aqueous extracts (A) of Commelina benghalensis $(\bullet)$, Cyperus difformis $(\circ)$ and Galinsoga parviflora $(\nabla)$. (B) means followed by the same letters do not differ by the Tukey test at a 5\% significance level. UFFS, Erechim/RS, 2015.

This reduction in radicle length can affect the competitive ability and productivity of the $L$. sativa species, and the potential for damage may be related to both the weed species and the aqueous extract concentration (Cândido et al. 2010, Hussain et al. 2011).

When comparing the extracts, it is possible to identify that $G$. parviflora and $C$. benghalensis were the most harmful species in the root length of $L$. sativa, for concentrations of 50,75 and $100 \%$ (Figure 1B). The production of allelochemicals is highly dependent on plant species and cultivation environment (Silva 2012). The species that produce these compounds should receive attention from researchers, for future isolation and identification of allelochemicals (Masum et al. 2016).

The results obtained for the length of $L$. sativa seedlings demonstrated the same behavior as the radicle length, with an exponential decrease for both variables. The increase in concentrations up to $100 \%$ caused a reduction of 72.4; 72.8 and $19.6 \%$ in the length of $L$. sativa seedlings, respectively for $C$. benghalensis, $C$. difformis and $G$. parviflora (Figure 2A). Silveira et al. (2012) observed that the lengths of root and seedling of $L$. sativa were affected by more than $60 \%$ with the use of extract from the bark of jurema-preta (Mimosa tenuiflora), results that may serve as a basis for further studies. 
When comparing the effect of weed extracts with each other, it was observed that the species $C$. difformis caused the greatest detrimental effect on the length of $L$. sativa seedlings, at concentrations of 25 and $50 \%$, equaling C. benghalensis in concentrations of 75 and 100\% (Figure 2B).

A

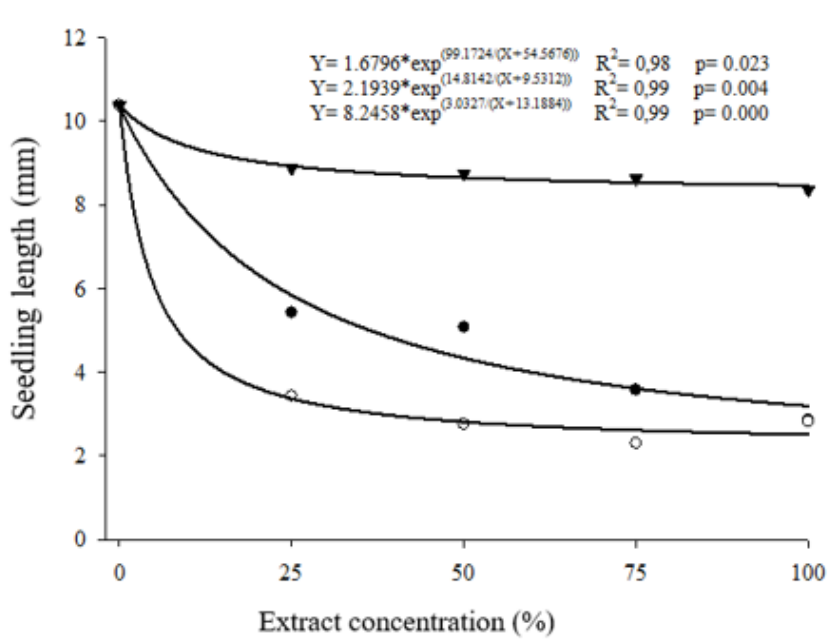

B

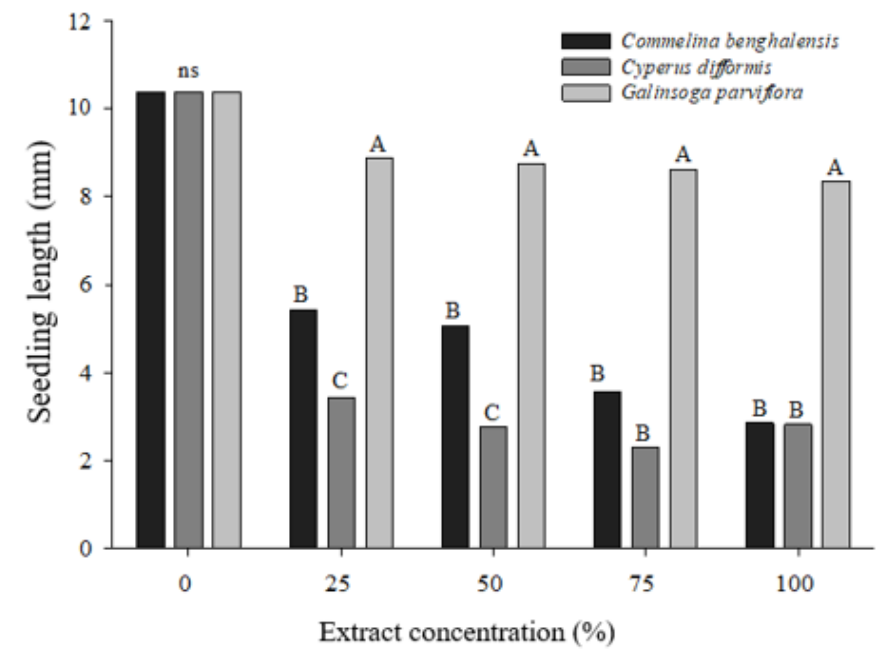

Figure 2. Seedling length $(\mathrm{mm})$ of Lactuca sativa as a function of the concentration of aqueous extracts $(A)$ of Commelina benghalensis $(\bullet)$, Cyperus difformis $(\circ)$ and Galinsoga parviflora $(\nabla)$. (B) means followed by the same letters do not differ by the Tukey test at a 5\% significance level. UFFS, Erechim/RS, 2015.

For the germination speed index there was a negative effect, represented by a linear decrease for the extract of C. difformis and an exponential decrease for G. parviflora. It is noteworthy that there was no fitting of the tested models to the germination speed index in the tested concentrations for the $C$. benghalensis extract data (Figure $3 \mathrm{~A}$ ). For the qualitative factor (different extracts) up to the concentration of $50 \%$, there was no difference between species, however in the highest concentrations (75 and 100\%) there was a decrease in this variable in the extract of $C$. difformis, not differing from G. parviflora (Figure 3B). Gatti et al. (2004) studying the allelopathic effect of Aristolochia esperanzae, observed similar results, that is, there was a delay in the germination and growth of $L$. sativa and Raphanus sativus L. with increased concentrations, so that the concentration of the plant extract becomes the main factor for satisfactory results with allelopathy (Cruz et al. 2000).

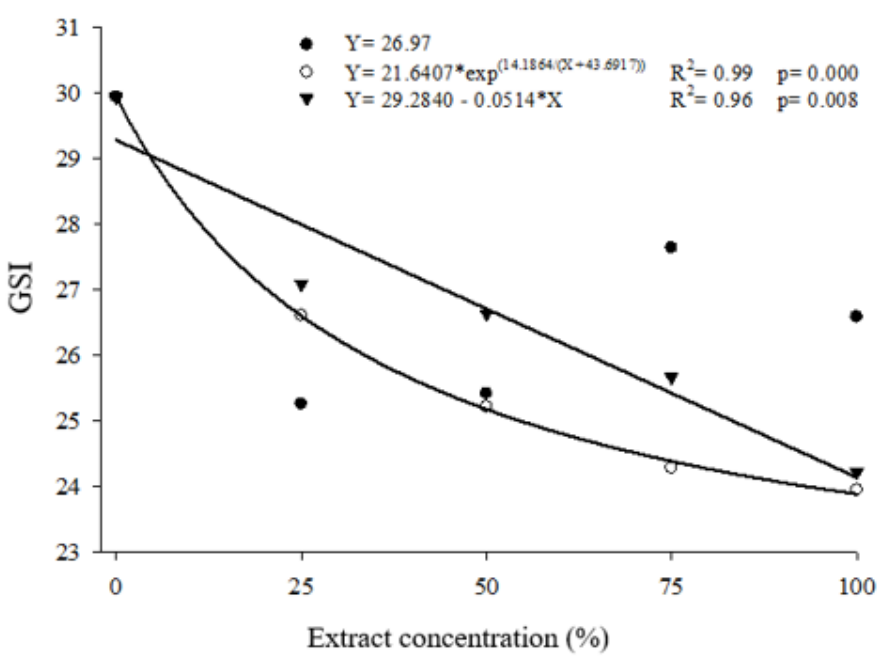

B

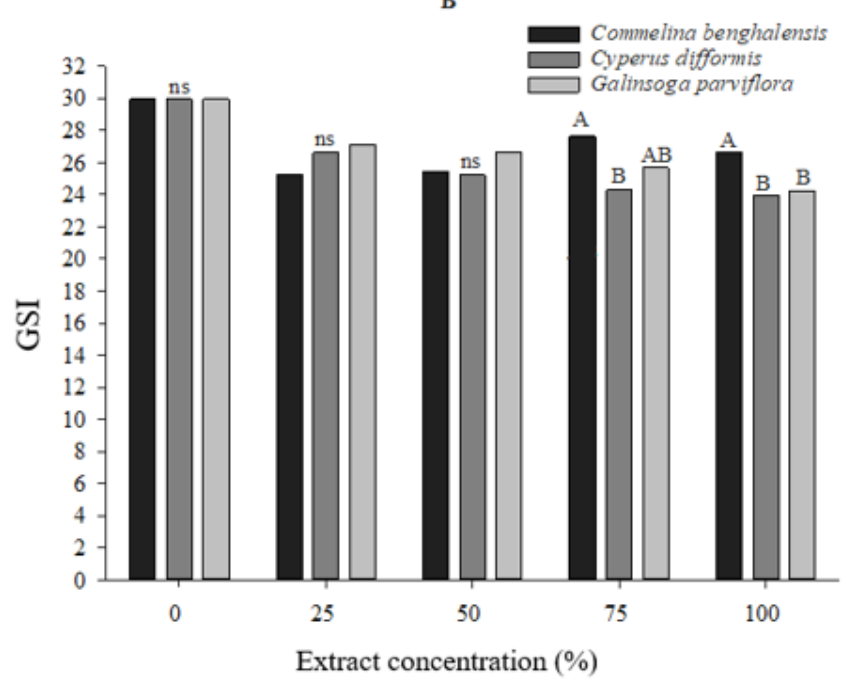

Figure 3. Germination speed index (GSI) of Lactuca sativa seeds as a function of the concentration of aqueous extracts

(A) of Commelina benghalensis ( $\bullet$ ), Cyperus difformis ( () and Galinsoga parviflora ( $\nabla)$. (B) means followed by the same letters do not differ by the Tukey test at a 5\% significance level. UFFS, Erechim/RS, 2015.

The results demonstrate that the tested models did not fit the data of $C$. benghalensis and G. parviflora, only of $C$. difformis, for the germination of $L$. sativa seeds (Figure 4A). When comparing the weeds with each other in each dose of the evaluated extracts, there was no significant effect on the germination of $L$. sativa (Figure 4B). In the tested concentrations, there was a $4 \%$ reduction in germination, linearly, only for $C$. difformis; the other species 
showed no reduction in this variable. In certain situations, no significant effect of weed extracts is observed on the germination of crops, but only on the speed of germination (Ferreira and Áquila 2000), which may interfere in the competitiveness of weeds over crops in the initial growth phase (Silva et al. 2007).
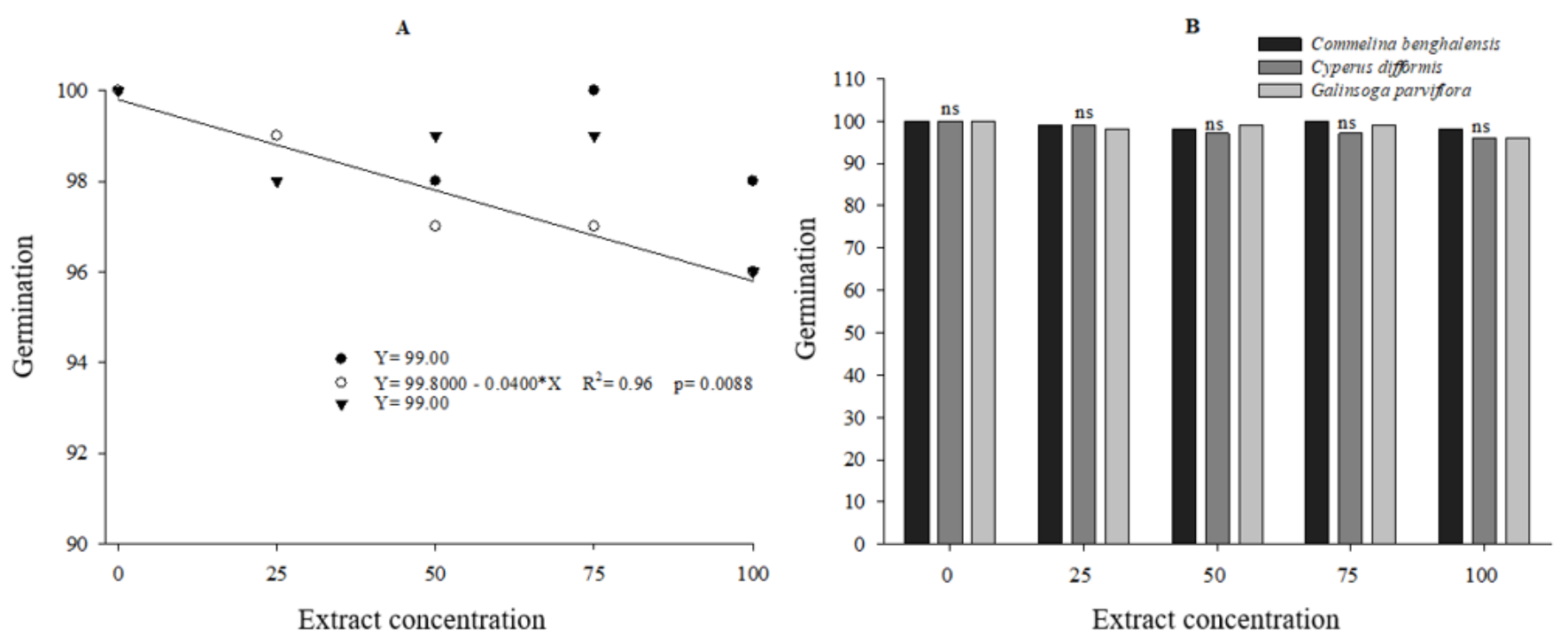

Figure 4. Germination (\%) of Lactuca sativa seeds according to the concentration of aqueous extracts (A) of Commelina benghalensis $(\bullet)$, Cyperus difformis $(\circ)$ and Galinsoga parviflora $(\nabla)$. (B) means followed by the same letters do not differ by the Tukey test at a 5\% significance level. UFFS, Erechim/RS, 2015.

As for the analysis of fresh matter, the results show that all doses of extracts compared to the control of the three weed species caused significant reductions in the variable under study, inhibiting the development of the crop. The species $C$. difformis was the weed that proved to be more harmful in the accumulation of fresh matter, reaching a reduction of $69.4 \%$ in the concentration $100 \%$ (Figure $5 \mathrm{~A}$ ). When using the concentration of $50 \%$ of $C$. benghalensis, there was a reduction of $64.9 \%$ in fresh matter, which had the greatest detrimental effect (Figure 5B). The results obtained for the germination and development of $L$. sativa establish $C$. difformis as a promising species for future research in the area. The concentration of phenols is one of the variables that can be evaluated in the extracts, in order to be a parameter to identify the degree of species allelopathy (Rashid et al. 2010).

A

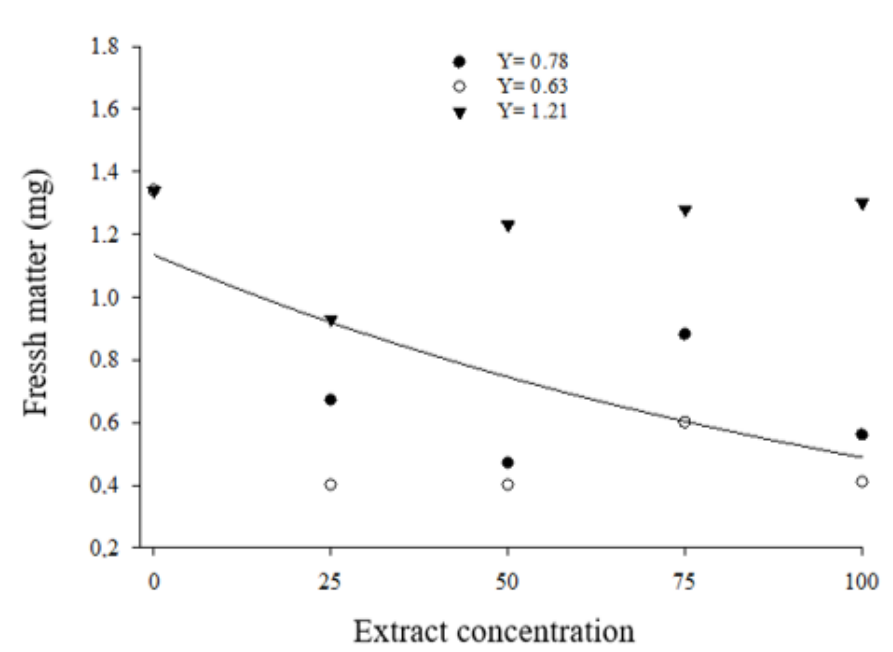

B

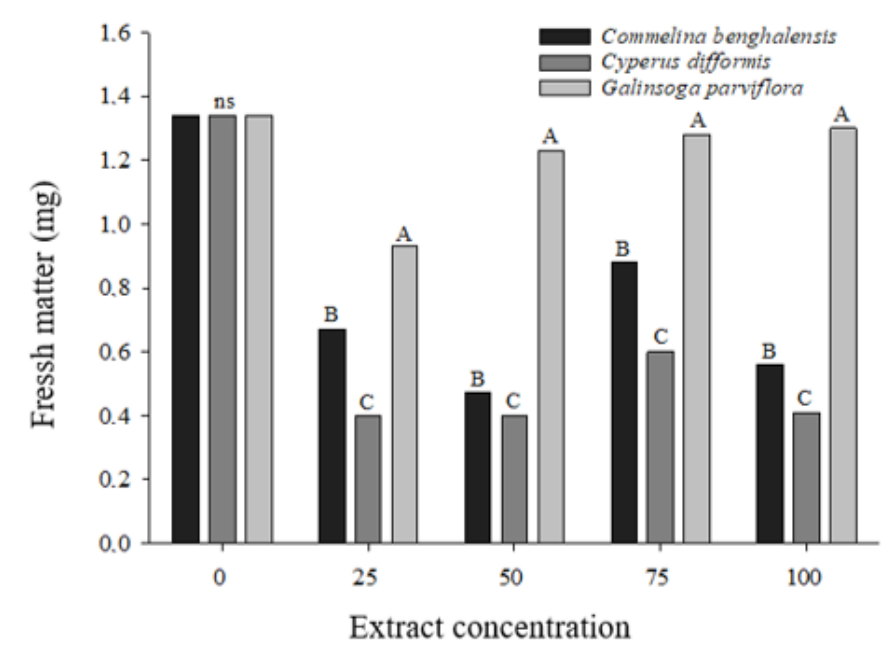

Figure 5. Fresh matter ( $\mathrm{mg} 20$ seedlings $^{-1}$ ) of Lactuca sativa as a function of the concentration of aqueous extracts (A) of Commelina benghalensis ( $\bullet$ ), Cyperus difformis $(\circ)$ and Galinsoga parviflora ( $\nabla)$. (B) means followed by the same letters do not differ by the Tukey test at a 5\% significance level. UFFS, Erechim/RS, 2015.

For dry matter of seedlings, there was, again, less accumulation with the increase of the concentrations of the extract of $C$. difformis, the other extracts did not show adjustment of the data to the tested models, being their averages of 0.22 and $0.23 \mathrm{mg}$ for 20 seedlings evaluated, respectively, for $C$. benghalensis and G. parviflora (Figure 6A). In the comparison of the extracts in the different concentrations it is possible to observe that $C$. benghalensis was the one that less influenced the dry matter of seedlings until the concentration of $75 \%$; however, 
when submitted to germination in the pure extract (100\%) it was, together with $C$. difformis, the species that most reduced the dry matter, approximately $73 \%$, in comparison with G. parviflora (Figure 6B).

A

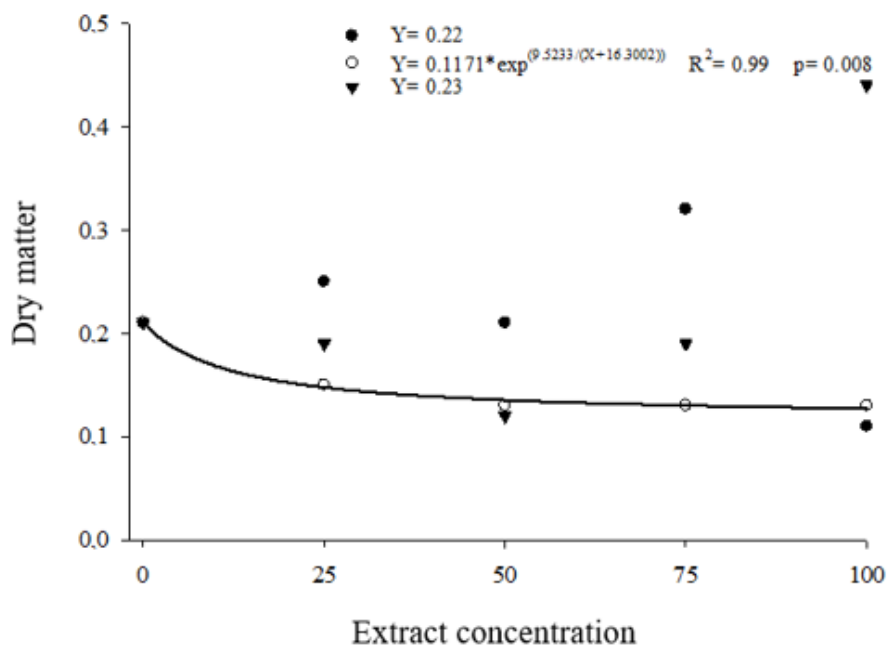

B

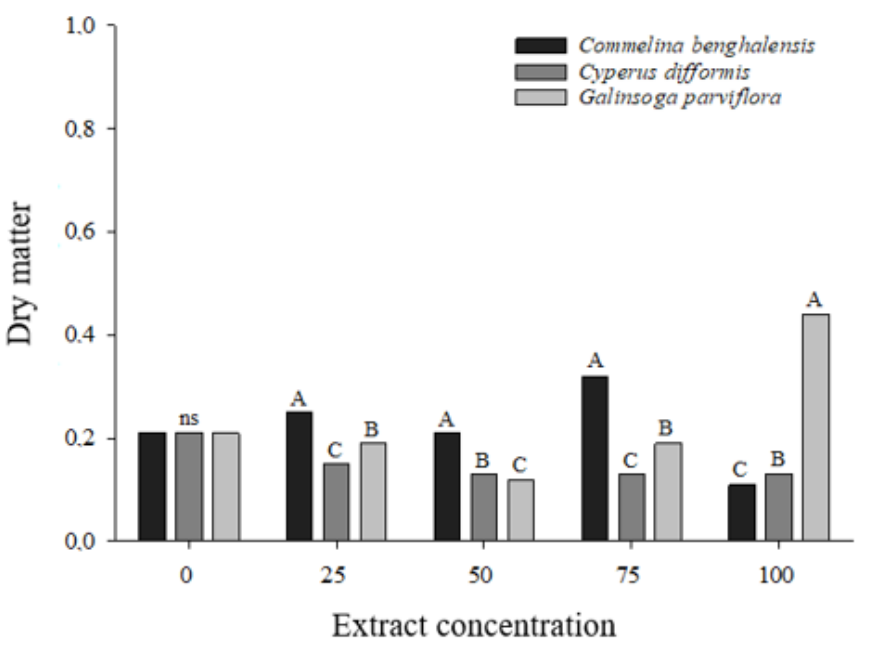

Figure 6. Dry matter ( $\mathrm{mg} 20$ seedlings $^{-1}$ ) of Lactuca sativa as a function of the concentration of aqueous extracts (A) of Commelina benghalensis $(\bullet)$, Cyperus difformis $(\circ)$ and Galinsoga parviflora $(\nabla)$. (B) means followed by the same letters do not differ by the Tukey test at a 5\% significance level. UFFS, Erechim/RS, 2015.

The detrimental effect of $C$. difformis on the initial development of $L$. sativa plants is noticeable, since the increase in the concentration of its extract affected all variables analyzed in the present study (Figures $1 \mathrm{~A}, 2 \mathrm{~A}, 3 \mathrm{~A}$, 4A, 5A and 6A). Similar results were found in a study by Tur et al. (2010), in which the species Duranta repens demonstrated a reduction in germination, fresh matter and dry matter of $L$. sativa and $L$. esculentum plants. Thus, C. difformis can be inserted in research programs that evaluate in field conditions the effect of allelochemicals of this species.

Experiment II - Influence of weed extracts on the growth of $L$. esculentum. In the experiment in which the behavior of $L$. esculentum seeds was evaluated, the initial growth of the seedling root system showed a reduction with increasing concentrations of the aqueous extracts of $C$. difformis and $G$. parviflora; the latter species caused a $50 \%$ reduction in the radicle length with a concentration of $42.7 \%$ of the extract (Figure $7 \mathrm{~A}$ ). For $C$. benghalensis, there was no adjustment of any tested model to the data. Even at very low concentrations of basil essential oil, the reduction in growth and development of $L$. esculentum plants is noticeable, especially with regard to epicotyl and hypocotyl (Rosado et al. 2009). This demonstrates the sensitivity of the species to the allelopathic components present in the plant compounds and it is possible to notice that the tested weed species produce some type of allelochemicals which are harmful to plant growth.

$A$

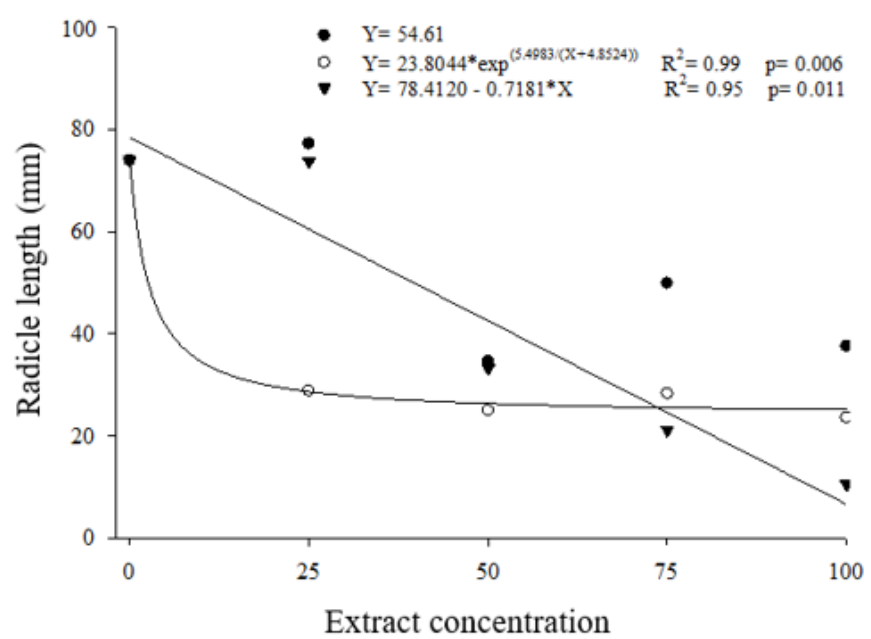

B

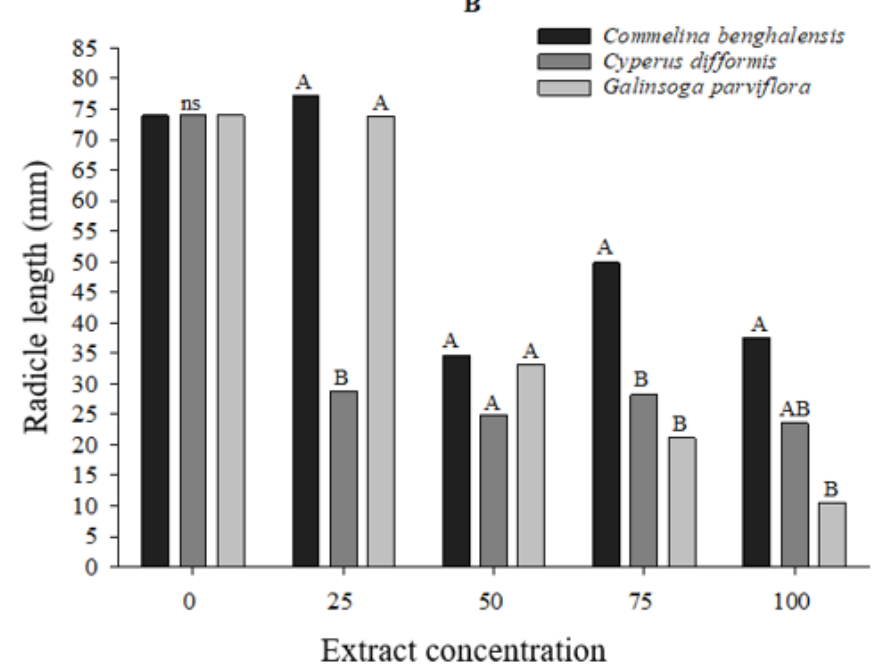

Figure 7. Radicle length ( $\mathrm{mm}$ ) of Licopersicum esculentum as a function of the concentration of aqueous extracts (A) of Commelina benghalensis $(\bullet)$, Cyperus difformis $(\circ)$ and Galinsoga parviflora $(\nabla)$. (B) means followed by the same letters do not differ by the Tukey test at a 5\% significance level. UFFS, Erechim/RS, 2015. 
At concentrations of 75 and $100 \%$, extracts of $C$. difformis and G. parviflora were the ones that most reduced the root length of $L$. esculentum seedlings, thus demonstrating their possible allelopathic potentials (Figure 7B). This potential, analyzed from the root length, is more dependent on the plant species than on the concentration of these compounds (Hussain et al. 2011).

The results demonstrate that seedling length was not affected when applying different concentrations of the extracts, as none of the tested models fit the data (Figure 8A). When compared to the different species of weeds, it was observed that $G$. parviflora and $C$. difformis, in all concentrations, in general, were the most harmful for the length of $L$. esculentum seedlings; this same effect was observed for $L$. sativa in germination with $C$. difformis (Figures 2B and 8B). Results of variations in the efficiency of extracts in the indicator plants have already been verified by Gao et al. (2009) in research to demonstrate the allelopathic effect of extracts of Hemistepta lyrate on rapeseed, turnip, wheat and cucumber, however, more strongly in species of the Brassicaceae family.
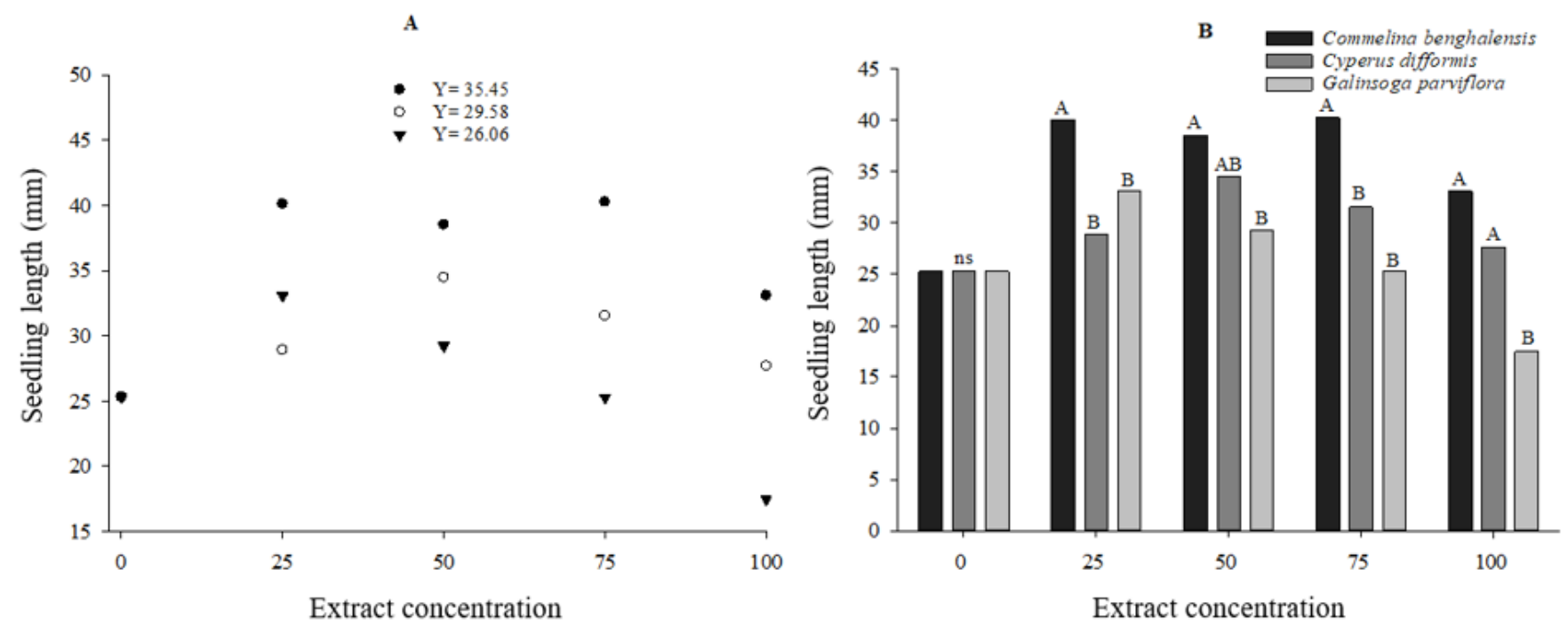

Figure 8. Seedling length ( $\mathrm{mm}$ ) of Licopersicum esculentum as a function of the concentration of aqueous extracts (A) of Commelina benghalensis $(\bullet)$, Cyperus difformis $(\circ)$ and Galinsoga parviflora $(\nabla)$. (B) means followed by the same letters do not differ by the Tukey test at a 5\% significance level. UFFS, Erechim/RS, 2015.

The concentrations of $C$. benghalensis negatively affected the germination speed of $L$. esculentum seeds, as the index was reduced by $50 \%$ at a concentration close to $88 \%$ of the extract (Figure $9 \mathrm{~A}$ ).

For species with allelopathic potential, such as Bidens pilosa, Cyperus rotundus and Euphorbia heterophylla studied by Gusman et al. (2011), the authors demonstrated a reduction in germination speed index with an increase in the concentrations of extracts from these plants. Comparing the species, the effect is observed only at concentrations of 25 and $75 \%$, with the extract of $G$. parviflora being the one that most reduced the germination speed index, not differing from $C$. difformis in the lowest concentration evaluated (Figure 9B).

The germination of $L$. esculentum seeds was reduced only in the concentration of $25 \%$ of the extract of $C$. difformis, differing approximately $41 \%$ in the average of the other two extracts (Figure 10A and B). The opposite was observed for the germination of $L$. sativa, which was more affected by the increase in the concentration of the extracts and there was no disparity regarding the studied extract (Figure $4 \mathrm{~A}$ and $\mathrm{B}$ ).

The tested models did not fit to the data of fresh and dry matters of $L$. esculentum seedlings for the different concentrations of the extracts (Figures $11 \mathrm{~A}$ and $12 \mathrm{~A}$ ). These two variables have a high correlation, because when there is a decrease in fresh matter, this is likely to be reflected in the dry matter of seedlings (Meinerz et al. 2015).

The extracts of $C$. difformis showed negative interference, with allelopathic effect, on the fresh and dry matters of seedlings of $L$. esculentum when compared with the other weed species (Figures 11B and 12B). In general, the allelopathic potential of this species was also higher in seedlings of $L$. sativa (Figures 1 to 6 ). This weed species is known as one of the most problematic in several cultures, and the genus is even reported to be very competitive with rice (Chauhan and Johnson 2010). Thus, this is an alternative that should be thoroughly studied for verification and uses in future weed management programs of agricultural crops.

These two experiments were the first steps to report the allelopathic effect of weeds on the growth of crops, in particular $L$. sativa and $L$. esculentum, so that research for the evaluation of allelochemicals present, their isolation and identification are the guidelines for future research. 

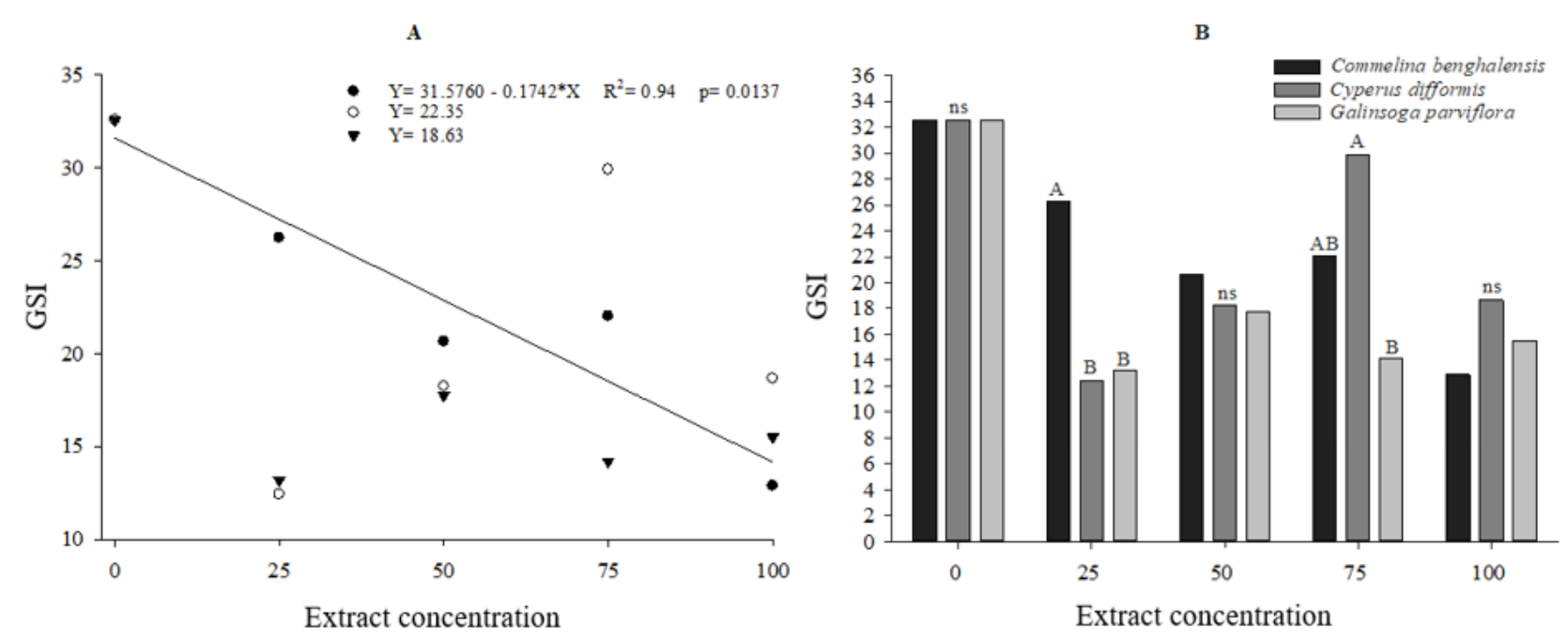

Figure 9. Germination speed index (GSI) of Licopersicum esculentum as a function of the concentration of aqueous extracts (A) of Commelina benghalensis ( $\bullet$ ), Cyperus difformis ( $\circ$ ) and Galinsoga parviflora ( $\nabla)$. (B) means followed by the same letters do not differ by the Tukey test at a 5\% significance level. UFFS, Erechim/RS, 2015.
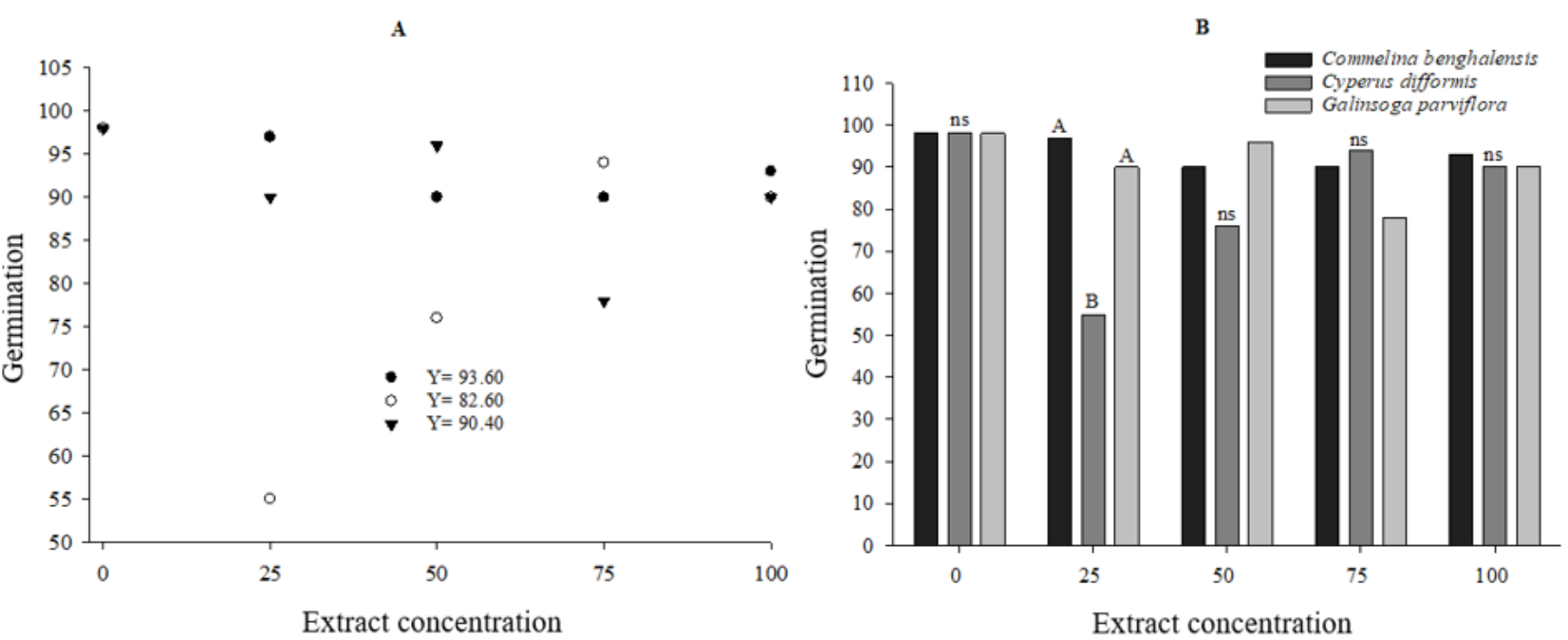

Figure 10. Germination (\%) of Licopersicum esculentum seeds as a function of the concentration of aqueous extracts (A) of Commelina benghalensis ( $\bullet$ ), Cyperus difformis ( $(0)$ and Galinsoga parviflora ( $\nabla)$. (B) means followed by the same letters do not differ by the Tukey test at a 5\% significance level. UFFS, Erechim/RS, 2015.
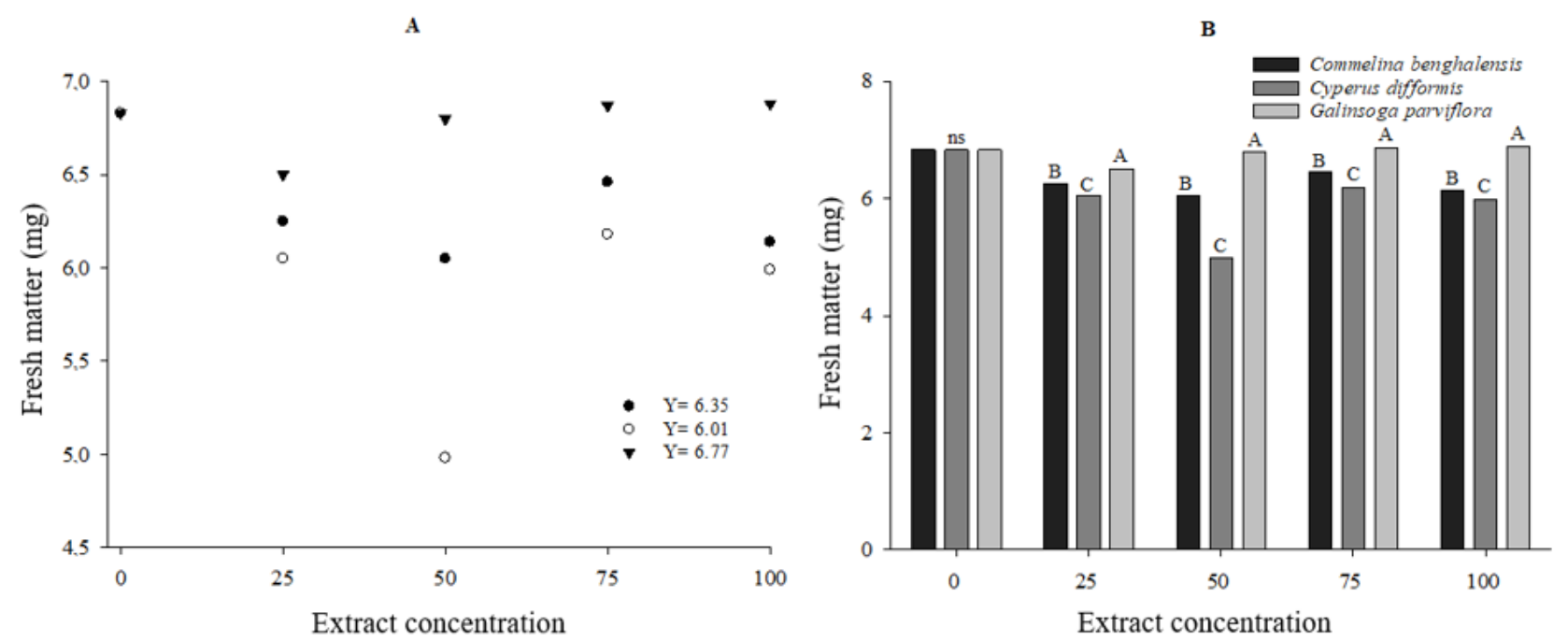

Figure 11. Fresh matter ( $\mathrm{mg}^{20}$ seedlings $^{-1}$ ) of Licopersicum esculentum as a function of the concentration of aqueous extracts (A) of Commelina benghalensis ( $\bullet$ ), Cyperus difformis $(\circ)$ and Galinsoga parviflora ( $\nabla) .{ }^{1}$ For the qualitative factor (B) means followed by the same letters do not differ by the Tukey test at a $5 \%$ significance level. UFFS,

Erechim/RS, 2015. 


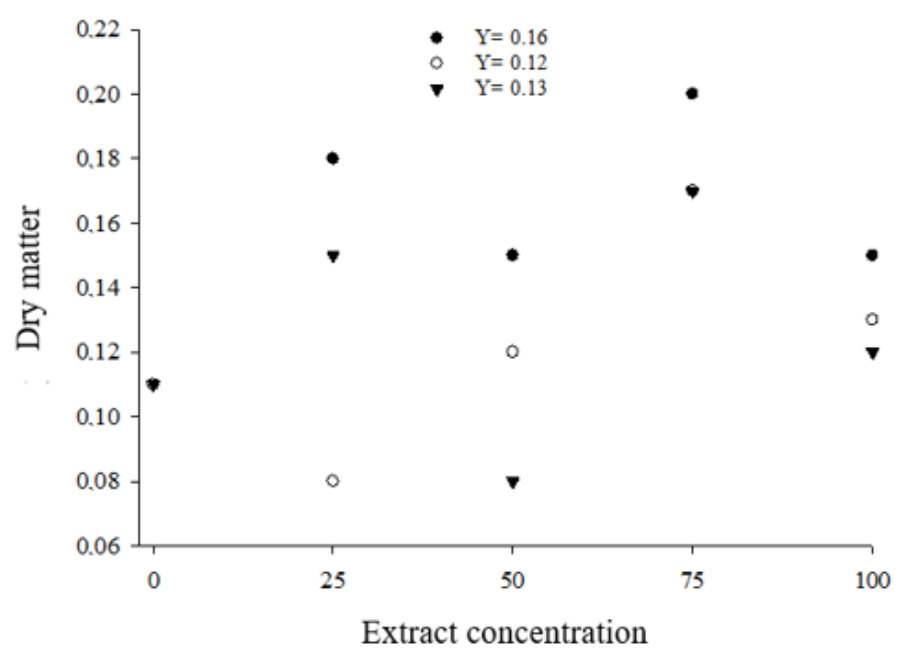

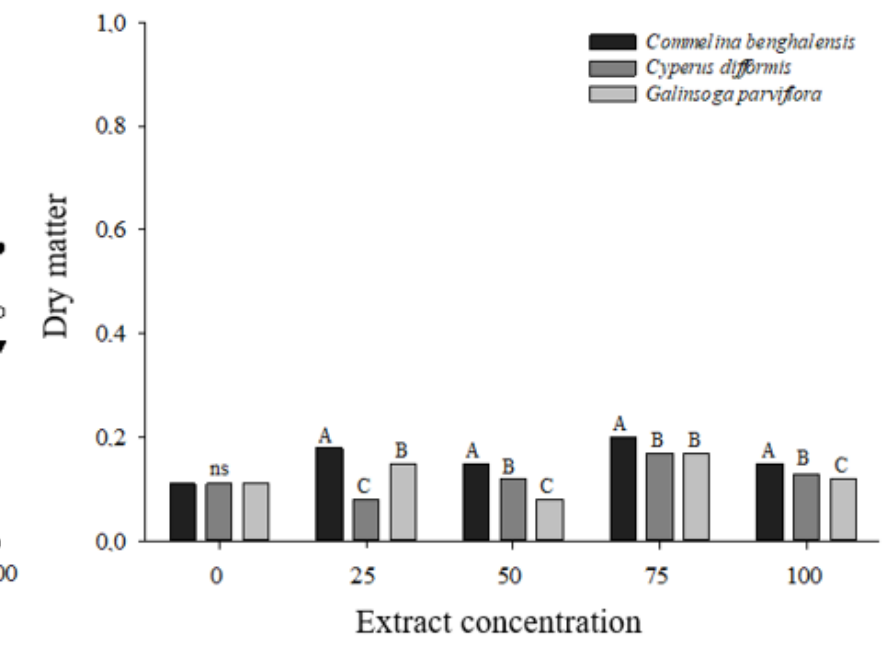

Figure 12. Dry matter ( $\mathrm{mg} 20$ seedlings $^{-1}$ ) of Licopersicum esculentum as a function of the concentration of aqueous extracts (A) of Commelina benghalensis $(\bullet)$, Cyperus difformis $(\circ)$ and Galinsoga parviflora $(\nabla) .{ }^{1}$ For the qualitative factor (B) means followed by the same letters do not differ by the Tukey test at a $5 \%$ significance level. UFFS, Erechim/RS, 2015.

In conclusion, Weeds Commelina benghalensis, Cyperus difformis and Galinsoga parviflora show allelopathic potential on the growth of Lactuca sativa and Lycopersicum esculentum crops. Among the evaluated variables, it can be seen that the greatest allelopathic effect occurred with the use of $C$. difformis extract, followed by $G$. parviflora and $C$. benghalensis. The potential allelopathic effect of weeds is directly related to the plant species used, as well as to the concentration of the aqueous extract present in the environment.

\section{References}

Barros ASR et al. 1999. Testes de frio. In: Krzyzanowski FC et al. (Eds.). Vigor de sementes: conceitos e testes. Londrina: ABRATES. cap 5. pp.1-15.

Brasil - Ministério da agricultura, pecuária e abastecimento. 2009. Regras para análise de sementes. Brasília. p. 395. Available at: http://www.agricultura.gov.br. Accessed on: Oct. 10, 2019.

Cândido ACS et al. 2010. Potencial alelopático de lixiviados das folhas de plantas invasoras pelo método sanduiche. Revista Brasileira de Biociências 8: 268-272.

Chauhan BS, Johnson DE. 2010. Implications of narrow crop row spacing and delayed Echinochloa colona and Echinochloa crus-galli emergence for weed growth and crop yield loss in aerobic rice. Field Crops Research 117: 177-182.

Cruz SEM et al. 2000. Plantas medicinais. Biotecnologia Ciência e Desenvolvimento 15: 28-34.

Fernandes LAV et al. 2007. Potencial alelopático de Merostachys multiramea Hackel sobre a germinação de Araucaria angustifolia (Bert.) Kuntze. Revista Acadêmica de Curitiba 5: 139-146.

Ferreira AG, Áquila MEA. 2000. Alelopatia: uma área emergente da ecofisiologia. Revista Brasileira de Fisiologia Vegetal 12: 175-204.

Fujji $Y$ et al. 2004. Assessment method for allelopathic effect from leaf litter leachates. Weed Biology and Management 4: 19-23.

Gao X et al. 2009. Allelopathic effects of Hemistepta lyrata on the germination and growth of wheat, sorghum, cucumber, rape, and radish seeds. Weed Biology and Management 9: 243-249.

Gatti $\mathrm{AB}$ et al. 2004. Efeito alelopático de Aristolochia esperanzae O. Kuntze na germinação e no crescimento de Lactuca sativa L. e Raphanus sativus L. Revista Acta Botânica Brasílica 18: 459-472.

Gusman SG et al. 2011. Potencial alelopático de extratos aquosos de Bidens pilosa L., Cyperus rotundus L. e Euphorbia heterophylla L. Iheringia. Série Botânica 66: 87-98.

Heap I. 2019. The International Survey of Herbicide Resistant Weeds. Available at: https://www.weedscience.org. Accessed on:Oct. 8, 2019.

Hussain Ml et al. 2011. Allelopathic potential of Acacia melanoxylon on the germination and root growth of native species. Weed Biology and Management 11: 18-28.

Inderjit, Callaway RM. 2003. Experimental design for the study of allelopathy. Plant and Soil 256: 1-11.

Jabran K et al. 2015. Allelopathy for weed control in agricultural systems. Crop Protection 72: 57-65.

Kong CH. 2010. Ecological pest management and control by using allelopathic weeds (Ageratum conyzoides, Ambrosia trifida, and Lantana camara) and their allelochemicals in China. Weed Biology and Management,10: 73-80.

Lorenzi H. 2017. Manual de identificação e controle de plantas daninhas: Plantio direto e convencional, 8 ed. Nova Odessa, SP: Instituto Plantarum.

Masum SM et al. 2016. Allelopathic potential of indigenous Bangladeshi rice varieties. Weed Biology and Management 16: 119-131.

Meinerz CC et al. 2015. Interferência alelopática na germinação de alface e tomate por derivados de avenca (Adiantum capillus-veneris L.), espinheira-santa (Maytenus ilicifoliar R.) e guaco (Mikania glomerata S.). Revista de Saúde e Biologia 10: 15-22.

Rashid MH et al. 2010. The allelopathic potential of kudzu (Pueraria montana). Weed Science,58: 47-55.

Rezende CP et al. 2003. Alelopatia e suas interações na formação e manejo de pastagens. Boletim Agropecuário. Lavras: UFLA. p.1-55.

Rizzardi MA. 2011. Associação de herbicidas no manejo de plantas daninhas resistentes. Revista Plantio Direto 122: 117-127. 
Rosado LDS et al. 2009. Alelopatia do extrato aquoso e do óleo essencial de folhas do manjericão "Maria Bonita" na germinação de alface, tomate e melissa. Revista Brasileira de Plantas Medicinais 11: 422-428.

Silva AA et al. 2007. Herbicidas: resistência de plantas. In: Silva AA, Silva F.J. (eds). Tópicos em Manejo de Plantas Daninhas. Viçosa: UFV. pp.279-324.

Silva PSS. 2012. Atuação dos aleloquímicos no organismo vegetal e formas de utilização da alelopatia na agronomia. Revista Biotemas 25: 6574.

Silveira PF et al. 2012. Potencial alelopático do extrato aquoso de cascas de jurema-preta no desenvolvimento inicial de alface. Revista Caatinga 25: 20-27.

Tur CM et al. 2010. Alelopatia de extratos aquosos de Duranta repens sobre a germinação e o crescimento inicial de Lactuca sativa e Lycopersicum esculentum. Revista Biotemas 23: 13-22.

Vasconcelos MCC et al. 2012. Interferência de plantas daninhas sobre plantas cultivadas. Revista Agropecuária Científica no Semiárido 8: 106 . 